Jacek TOMCZYK

WFCh UKSW Warszawa

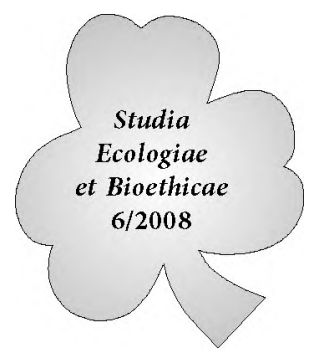

Anna DYGUDAJ

\title{
Swoistość ludzkiej kultury - wampiryzm
}

Wśród wielu cech naszego gatunku podkreślana jest umiejętność tworzenia kultury, stąd określa się człowieka mianem Animal culturale. Oznacza ono, że spośród całego świata ożywionego tylko reprezentanci naszego gatunku potrafią uzewnętrznić swoje przemyślenia i przeżycia. Malarstwo, rzeźba, narzędzia, ozdoby to tylko niektóre materialne przejawy kulturowych zachowań człowieka, które stanowią odwzorowanie bogactwa ludzkiego wnętrza. Jednym z ważniejszych elementów kultury jest wytworzenie całego, zwartego systemu wierzeń i religijnych przekonań. \owarzyszy on istotom naszego gatunku od tysiącleci, a mogą tego dowodzić choćby spektakularne malowidła $z$ jaskini Lascaux czy Altamiry, które przedstawiają zwierzęta i z rzadka ludzi. Zastanawiającym jest fakt, że sztuka ta nie zawiera dokładnego opisu świata - brak tu bowiem flory, krajobrazów czy scen przedstawiających codzienne życie. Zdobione jaskinie nie są zatem jedynie zbiorowiskiem przypadkowych obrazów, lecz raczej wyselekcjonowanych scen. Nasi paleolityczni przodkowie zaczęli poszukiwać naturalnych i ponadnaturalnych przyczyn regularności i cykliczności obserwowanej w świecie przyrody. W ich umysłach powstała swoista koncepcja natury i relacja pomiędzy światem materialnym, a światem 'duchów'. Zaczęli tworzyć nie tylko sztukę, ale i wykorzystywać obrzędy magiczne. Oczywistym jest, że wszystko to pozostaje w sferze większych lub mniejszych domysłów. 『ym niemniej, człowiek jawi się jako istota poszukująca uzasadnienia swego istnienia i tego, co dokonuje się w otaczającym go świecie. Jednym z nurtujących człowieka problemów było poszukiwanie przyczyn nagłych i niewytłumaczalnych zgonów. Interpretacja tych zjawisk często wykraczała poza racjonalne przesłanki. Poszukiwano zatem ich źródeł w tym co poza-naturalne i nadprzyrodzone. Jednym z wyjaśnień była ingerencja diabolicznej istoty określanej mianem „wampira”.

\section{Etymologia słowa „wampir”}

Pochodzenie słowa „wampir” jest bardzo złożone i nie zostało do końca wyjaśnione. Różne źródła wskazują na odmienne pochodzenie tego terminu. Rossel 
Hope Robbins jest zdania, iż słowo „wampir” pochodzi z języka węgierskiego i w zbliżonych formach pojawia się również w językach słowiańskich. Nie wyklucza ona także etymologicznego powiązania z tureckim ubek (czarownik). Brückner poszukuje $z$ kolei korzeni tego słowa w rejonie bałkańskim, gdyż tam właśnie funkcjonuje największy zasób wierzeń o wampirach ${ }^{1}$. Zdaniem Jerzego Strzelczyka, nazwa "wampir” jest rdzennie słowiańska, sięgająca co najmniej IV wieku. Mogą na to wskazywać opowiadania o wampirach i sposobach walki z nimi, znane zarówno u Słowian południowych (w Serbii, Chorwacji, Bułgarii), jak i zachodnich (w Polsce, Czechach, Słowacji). Słowo to później zostało przejęte przez inne ludy np. germańskie. Bez wątpienia w historii tego terminu przeplatają się wpływy rozmaitych kultur - rosyjskiej upyr, polskiej wypierz lub upiór, bułgarskiej vepir, czeskiej upir, północnogreckiej wampira i serbskiej wampir ${ }^{2}$. Ostatecznie termin ten rozpowszechnił się i zakorzenił w języku polskim, rosyjskim, czeskim i nowogrodzkim i jest używany do dziś jako „wampir”.

Słowu „wampir” odpowiada łacińskie strix (polska „strzyga”), oraz portugalskie brusa (termin oznaczający kobietę - ptaka wysysającego krew z dzieci). Słowo to po raz pierwszy trafiło do języka angielskiego w roku 1743 i używano je do określenia ciała osoby zmarłej, która ożywiana przez złego ducha, wychodzi nocą z grobu i wypija krew żyjących. Dopiero kilka lat później, w roku 1762, termin ten pojawił się jako określenie nietoperzy, które miały rzekomo atakować zwierzęta ${ }^{3}$. Stąd w późniejszych tradycyjnych wyobrażeniach wampira przedstawiano, jako na wpół nietoperza na wpół człowieka. Pierwotnie jednak za wampira uważano bądź demona, który wstąpił w ludzkie ciało, bądź duszę samego zmarłego przebywającą w ciele.

Wampir, zwany po polsku upirem i upirzyca, wąpierzem, był okrutną istotą wzbudzającą lęk. Mianem wampira najczęściej piętnowano osoby odznaczające się niespotykanymi powszechnie cechami, bądź uczestniczącymi w powszechnie nieakceptowanych zdarzeniach. Według wierzeń ludowych, dziecko rodzące się z zębami lub z pogrubionymi dziąsłami, mogło zostać wampirem. Wampirami stawali się również ludzie wiodący „żywot występny i rozwiązły”, a także osoby, na których w chwili zgonu ciążyła klątwa lub przekleństwo. Opinię taką wyrażał Leone Allacci, siedemnastowieczny teolog, w dziele De Graecorum Hodie Quorundam Opinationibus z 1645 roku. W wampiry przeistoczyć się mogli ludzie zamordowani lub zmarli śmiercią gwałtowną (np. w wyniku epidemii). Wampirem stawała się osoba bez względu na płeć - zarówno zmarły mężczyzna, jak i kobieta. Wiek również nie odgrywał tu roli.

Gieysztor A., Mitologia Słowian, Wyd. Artystyczne i Filmowe, Warszawa 1986, 222.

Strzelczy J., Mity, podania i wierzenia dawnych Stowian, Dom Wyd. Rebis, Poznań 1998, 219-220.

3 Rob Bins R.H., Encyklopedia czarów i demonologii, Dom Wyd. Belona, Warszawa 1998, 307. 
W starożytnej Grecji odpowiednikiem wampira była lamia - upiorzyca, uprowadzająca małe dzieci i pozbawiająca ludzi krwi, zaś w Rzymie były to lemury (złośliwe duchy zmarłych), którym 9 listopada i 13 maja składano nocą ofiary przebłagalne ${ }^{4}$.

Najczęściej wampiry łączono z wilkołakami, jednak w przeciwieństwie do nich, wampiry były „żywymi trupami” i do swej egzystencji potrzebowały wyłącznie krwi ${ }^{5}$. Dawne wierzenia ludowe mówią o różnych zachowaniach wampirów. Niekiedy miały one tylko chodzić nocą koło swojego domu, lub po innych miejscach, nie czyniąc nikomu nic złego, wydając przy tym jedynie przerażaąace jęki. Innym razem wypijały nocą krew $z$ ludzi, bądź ze zwierząt domowych, np. koni lub krów. Najważniejszym wątkiem występującym w opowiadaniach o wampirach było ich pastwienie się nad istotami żywymi, które zazwyczaj kończyło się zabiciem ofiary. Wampir najczęściej pił lub ssał krew z serca lub z żył swych ofiar, rzadziej dusił i pożerał ich mięso. Powszechnie bowiem wierzono, że dzięki wypiciu krwi bądź spożyciu narządów człowieka przejmuje się jego zalety, siłę, życie i duszę. Krew jako siedlisko życia uchodziła więc za ulubiony pokarm duchów ludzi zmarłych ${ }^{6}$. Osoby, którym wyssano krew, same stawały się wampirami. W latach 1693 i 1694 gazety francuskie i holenderskie donosiły o „krwiopijcach” pojawiających się w Polsce oraz Rosji. Według opinii rozpowszechnionej wśród tych narodów, demony te atakowały między południem a północą wysysając krew z ludzi i zwierząt tak łapczywie, że przelewała im się ona ustami, nosem lub uszami? ${ }^{7}$ Według niektórych podań, jedną z charakterystycznych cech wampira jest wstręt do światła, które pozbawia go nadnaturalnej siły. Stąd upiór wiódł przeważnie nocny tryb życia ${ }^{8}$. W średniowiecznych wierzeniach niezwykle mocno ugruntowało się przekonanie, o wzmożonej aktywności wampirów w czasie szerzących się zaraz i morów. Bez wątpienia czynnikiem podsycającym te wierzenia była szybka śmierć kilku osób w jednej rodzinie, w krótkim przedziale czasowym. Stąd w Europie można odnotować nieomal „epidemie” wampiryzmu, które pokrywają się z czasowym występowaniem pomorów ${ }^{9}$.

\footnotetext{
Lurker M., Leksykon bóstw i demonów, Dom Wyd. Bellona, Warszawa 1999, 154.

Kempiński A.M., Stownik mitologii ludów indoeuropejskich, Wyd. SAWW, Poznań 1993, 450.

Moszyński K., Kultura ludowa Stowian, Książka i Wiedza, Warszawa 1967, 628-629.

Plancy C., Stownik wiedzy tajemnej, Oficyna Wyd. Polaczek, Warszawa 1993, 190.

D’Asier A., Ludzkość pośmiertna, Studium nad widmami i marami, Nakład Redakcji „Niwy”, Aleksandrya $1896,86$.

9 Moszyński K., Kultura..., dz. cyt., 662.
} 


\section{Praktyki anty-wampiryczne}

Zarówno literatura mitologiczna, jak i teksty religijne przesycone są bądź diabolicznymi stworzeniami, bądź błąkającymi się w zaświatach ucieleśnionymi duchami, które na różne sposoby miały atakować i zagrażać ludziom. Stąd w tradycji, nie tylko ludowej, powstały dziesiątki praktyk anty-wampirycznych, mających na celu ochronę ludzi i ich dobytku przed przerażającymi kreaturami. W wiekach średnich wielu zakonników i księży walczyło $\mathrm{z}$ wampiryzmem. Ksiądz Jan Bohomolec w 1775 roku napisał: „Upiory są to, według powszechnego mniemania, ciała umarłych, nieikim, iż tak rzekę, sposobem ożywione. \e nieczekaiąc powszechnego zmartwychwstania, powstaią z trumny przed czasem; z grobów wychodzą; na domy nachodzą; ludzi, których mogą duszą; krew wysysają; na ołtarze łażą, one krwawią, świece łamią; y innych wiele sprośności y morderstwa czynią"10.

Znanych było wiele sposobów ochrony przed wampirami, a większość z nich sięgała początków średniowiecza. Stosowano je zarówno w czasie pochówku, jak i po pogrzebie. Zaspokajano dzięki temu potrzeby wampira oraz uniemożliwiano mu ewentualne wydostanie się z grobu ${ }^{11}$. Ponieważ duch zmarłego śmiercią nagłą odznaczał się, jak uważano, o wiele większą złośliwością i szkodliwością, aniżeli w innych przypadkach, dlatego też grzebano go bez zwykłych obrzędów pogrzebowych. Na pochówki wybierano nie cmentarze, lecz miejsca odosobnione i graniczne, takie jak lasy, pola, bagna i rozstaje dróg. Czyniono tak, aby zmarli nie straszyli podróżnych i przechodniów. Fischer przybliża nam te zwyczaje w swojej książce: „Na Śląsku chowa się samobójców na drogach rozstajnych, często pod murem (...). W powiecie olkuskim powieszonego nie wiozą na cmentarz drogą, lecz granicami (...). W Małopolsce zachodniej chowają samobójców pod murem, w rogach cmentarza, na ścieżkach (...). Na Podgórzu wschodnio - małopolskim wisielca nie można grzebać na cmentarzu, tylko na granicy wsi (...). U górali nadłomnickich płód poroniony chowają pod murem cmentarza (...) dzieci nieżywo urodzone grzebie się także pod mur"12. Informacje te potwierdzają znaleziska archeologiczne. Większość grobów wampirów zlokalizowana była na peryferiach cmentarzy. Nie znajdowano w nich typowego wyposażenia zmarłego, np. kabłączków, noży, paciorków, charakterystycznego dla pochówków wczesnego chrześcijaństwa ${ }^{13}$. Swiadczy o tym choćby teren cmentarzyska ze

10 KrzemińsKa A., Kolek na wampira, „Polityka” 42(2003)76.

11 NiEWĘGŁowski A., Obrzq̨dek pogrzebowy ludności kultury przeworskiej na przełomie er, Zakład Narodowy Ossolińskich, Wrocław 1981, 473.

12 Fischer A., Zwyczaje pogrzebowe ludu polskiego, Zakład Narodowy Ossolińskich, Lwów 1921, $355 \mathrm{nn}$.

13 Samsonowicz H. (red.), Dzieje Sandomierza, średniowiecze, Polskie 冈owarzystwo Historyczne, Warszawa 1993, 70. 
Wzgórza Świętojakubskiego z Sandomierza. Choć większość nekropolii została zniszczona w wyniku prac budowlanych, to jej fragment ograniczony wzgórzem pozostał nienaruszony. Odkryte tu pochówki brzegowe wykazują wiele cechę praktyk anty-wampirycznych ${ }^{14}$.

Słowiańscy chłopi znali bardzo wiele sposobów mających unieszkodliwić zmarłego, o którym sądzono, że może stać się upiorem. Na terenie Moraw i na Ukrainie powszechne było przekonanie, iż trzykrotne rzucenie ziemi na trumnę chroni przed działalnością wampira. Podobną moc miał zwyczaj rzucania kamieni na mogiły, bądź usypywania na niej głazów. (por. rys.1)

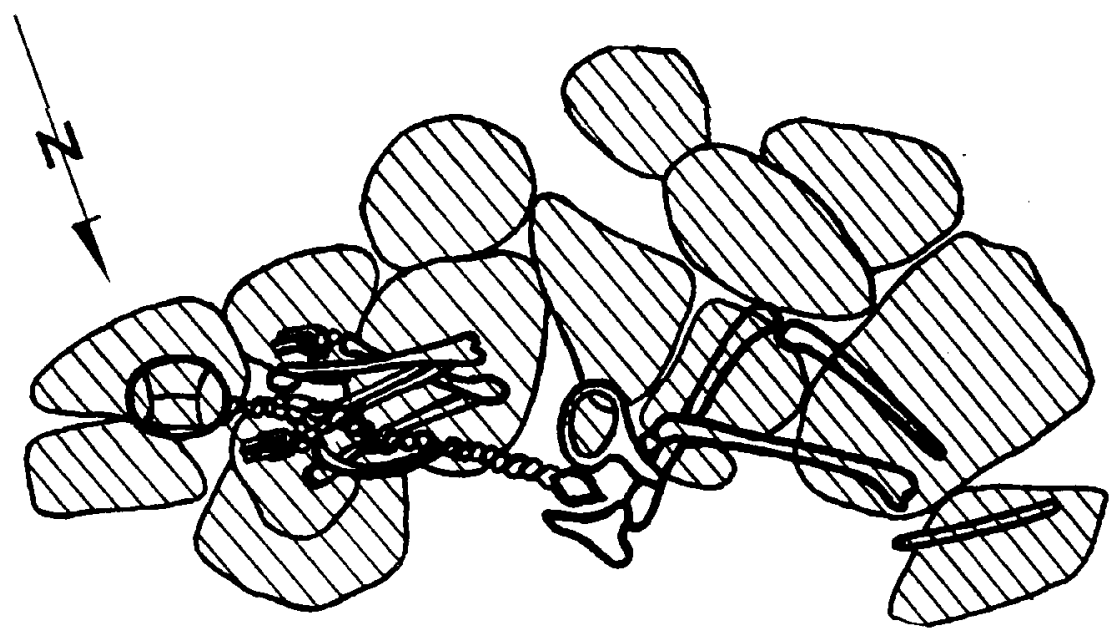

Ryc. 1: Grób upiora pod brukiem kamiennym, $z$ cmentarzyska $w$ Radomiu (II połowa XI w.). Szkielet człowieka dorosłego, którego przed pochowaniem skrępowano ${ }^{15}$.

Na mogiłach tych, którzy w opinii ludu mogli stać się upiorami sadzono ciernie, które miały powstrzymać mary przed ich opuszczeniem. Niekiedy też kolce umieszczono w głębi grobu, aby kopiący nieboszczyk natrafił na kłujące i raniące elementy rośliny i nie mógł przez to opuścić swego legowiska. Innym sposobem zaradczym było wbijanie w grób kawałka żelaza, np. starego noża lub gwoździa, ostrzem ku dołowi. Kolce wbijano między innymi pod język, co miało na celu uniemożliwić upiorowi pożerania ciała i ssania krwi ofiary. Umieszczano je również za paznokciami palców u nóg, w brzuchu w okolicach pępka oraz na plecach w odcinku krzyżowym kręgosłupa. Zmarłemu wkładano również kamyk lub pieniądz pod język. Wspomniane praktyki znajdują swoje potwierdzenie na

\footnotetext{
4 Stanaszek $€$, Praktyki anty-wampiryczne $w$ XI wieku stosowane na terenie cmentarzyska szkieletowego na Wzgórzu Świętojakubskim w Sandomierzu, „Biuletyn Antropologiczny” t. II, 1998, 21.

15 Gieysztor A., Mitologia..., dz. cyt., 223.
} 
wspomnianym już cmentarzysku z Sandomierza. W grobie nr 9 odnaleziono dwa szkielety, pod jednym $z$ nich w okolicy czaszki i klatki piersiowej odkryto między innymi zardzewiały gwóźdź kowny i podłużny fragment mocno przerdzewiałego przedmiotu żelaznego (prawdopodobnie sierpa) ${ }^{16}$. Natomiast w grobie $\mathrm{nr}$ 41 odkryto szkielet kobiety, która miała umieszczoną w okolicy żuchwy monetę, mającą chronić przed wpływem złego ducha ${ }^{17}$.

W Polsce wczesnopiastowskiej panował zwyczaj układania ciała zmarłego w pozycji wyprostowanej na wznak, z głową w kierunku zachodnim. Jednak groby ludzi uznanych powszechnie za upiory różniły się od pochówków zwykłych „śmiertelników”. Ciało ich było ułożone w nienaturalnej pozycji, zdarzało się, że ręce wiązano na plecach. Mogiły takie często zawierały niekompletne szkielety lub przemieszane kości. Prawdopodobnie był to rezultat ćwiartowania zmarłego. Podobnie, w celu uniemożliwienia wampirowi opuszczenia grobu kaleczono mu pięty lub przecinano ścięgna pod kolanami. Najpewniejszym sposobem było jednak obcięcie głowy i umieszczenie jej między nogami, tak aby wampir nie mógł jej uchwycić rękami. Sposób odcinania głowy jest źródłem wierzeń o upiorach niosących własną głowę w rękach. 囚aki rodzaj pochówku znany jest w Polsce jedynie ze stanowiska w Starym Brześciu Kujawskim. (por. fot. 1)

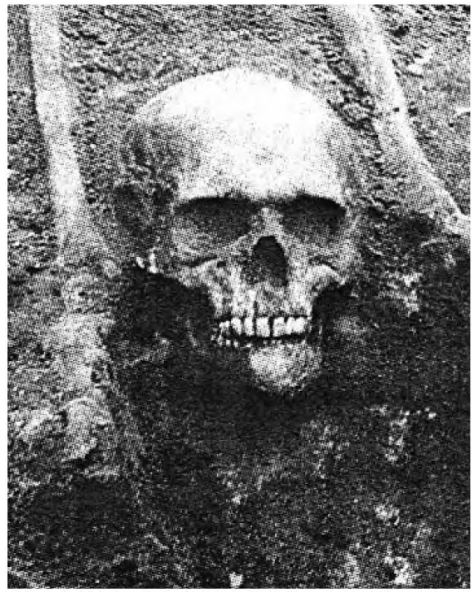

Fot. 1: Grób odnaleziony w Starym Brześciu Kujawskim ${ }^{18}$

Inną praktyką anty-wampiryczną było odcięcie głowy i umieszczenie jej powyżej korpusu ciała. Pochówek tego typu odkryto na wczesnośredniowiecznym cmentarzysku w Kałdusie (powiat Chełmno). (por. rys. 2)

16 GĄssowski J., Materialy do osadnictwa wczesnośredniowiecznego Sandomierszczyzny, „Materiały Wczesnośredniowieczne"6(1969)404-405.

17 Miśkitwicz M., Wczesnośredniowieczny obrzadek pogrzebowy na plaskich cmentarzyskach szkieletowych w Polsce, „Materiały Wczesnośredniowieczne”6(1969)254. 


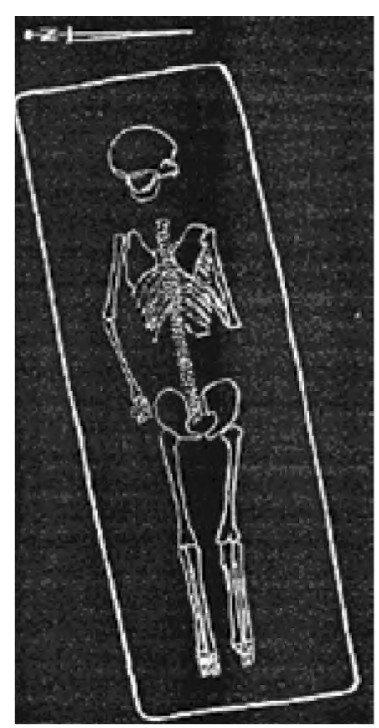

Ryc. 2: Wampir z Kałduna-grób nr $24^{19}$

Popularną metodą zapobiegania wampiryzmowi było przebijanie zmarłego cierniami lub ostrymi kołkami (w zależności od regionu - na południu głogowymi, na północy najczęściej osikowymi; czasami również klonowymi lub lipowymi). Według zwyczajów po odkopaniu grobu należało przebić pierś wampira kołkiem lub zębem od brony. Zalecano również przebicie jego głowy gwoździem zelaznym. W 1870 roku w pokładach piasku koło cegielni przy drodze z Piotrkowa Ørybunalskiego do wsi Byki odnaleziona została czaszka ludzka przebita na wylot długim kilkudziesięciocentymetrowym gwoździem. (por. ryc. 3) Upiora pozbawiano również często dolnej szczęki, bądź rozbijano czaszkę drewnianym palem. Biskup Burchard z Wormacji na początku XI wieku opisał przypadek wampiryzmu - zmarłe bez chrztu dziecko niewiasty chowały w miejscu tajemnym i przekłuwały je drewnianym kołem, by z grobu nie wstało i ludzi nie dusi$\mathfrak{1 0}^{20}$. Przedmiotami używanymi do okaleczenia zmarłego były zaostrzone kołki, ciernie, zęby od brony, żelazne kolce, groty strzał bądź gwoździe. Najczęściej jednak ograniczano się do przewrócenia nieboszczyka twarzą ku dołowi, „aby gryzł ziemię". W takiej pozycji został pochowany osobnik męski (nr grobu 90) z cmentarzyska na Wzgórzu Świętojakubskim ${ }^{21}$. Dodatkowo w celu obrony, w trumnie umieszczano rozmaite narzędzia - sierpy, noże, które miały upiora kaleczyć przy próbie opuszczenia miejsca spoczynku.

18 Stanaszek Ł., Wampiry, „Wiedza i życie”1(2001)37.

19 Stanaszek E., Pochówki wampirów w Polsce wczesnopiastowskiej, „Archeologia”2 (1999)39.

20 Brückner A., Mitologia słowiańska i polska, PWN, Warszawa 1985, 279.

21 Stanaszek E, Praktyki..., art. cyt., 24. 


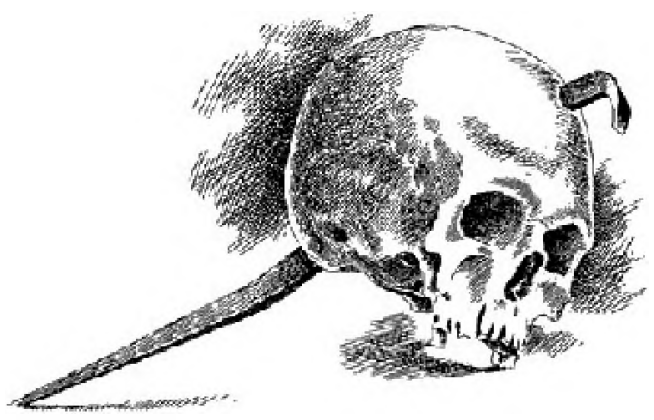

Ryc. 3: Czaszka przebita gwoździem odnaleziona w 1870 roku w okolicach Piotrkowa koto Radomia ${ }^{22}$.

Jedną z dróg eliminacji wampira było zerwanie nadnaturalnego połączenia mary z ciałem zmarłego. Należało jedno z nich zniszczyć, a ponieważ z marą nie można było skutecznie walczyć, zatem odgrzebywano ciała i je palono ${ }^{23}$. W jednej z czeskich kronik z XV wieku zanotowano dwa takie przypadki - w latach 1336 i 1344. Oto jeden $z$ nich: „W Czechach (...) we wsi Blow umarł pasterz. Đen wstając co nocy chodził wokół po wszystkich wsiach, ludzi straszył, dusił i wywoływał. A gdy został kołkiem przebity, mówił szydząc: a to mi bardzo zaszkodzili, bo mi dali laskę, żebym się mógł psom opędzać! A gdy go odkopali, był wzdęty jak wół i ryczał strasznie. A gdy go rzucono w ogień, ktoś porwawszy kij wbił w niego, i natychmiast trysnęła krew jak z naczynia. Gdy został wykopany i włożony na wóz, ściągnął nogi ku sobie jak żywy, ale gdy go spalono, całe zło ustało”24.

Kolejnym środkiem ochrony przed wampirami były niektóre rośliny np. mak. W zwyczajach pogrzebowych uznawano go za środek zaradczy przeciw błądzącym duszom zmarłych. Drobinki maku sypane na mogiłę uniemożliwiały wychodzącemu $\mathrm{z}$ niej duchowi wędrówkę, który zajmował się ich liczeniem i zaprzestawał niepokojenia ludzi. W Prusach zachodnich sypano garść maku do trumny umarłemu, który według tamtejszych wierzeń, zjadał po jednym ziarnku co roku i przez to oszczędzał żywych. Na uwagę zasługuje fakt, iż w zwyczajach pogrzebowych gdzieniegdzie do dziś używa się maku, jako środka zapobiegającego pojawieniu się złych duchów ${ }^{25}$. Czosnek (Allium sativum) to kolejna roślina mająca moc obronną przed wampirami. W Serbii smarowano nim drzwi domostw, bądź pod postacią plecionego wieńca wieszano w izbach, aby oddalić moce zła.

22 Stanaszek Ł., Wampiry..., art.cyt., 40.

23 D'Asier A., Ludzkość..., dz.cyt, 265.

24 Stanasze K E., Wampiry..., art. cyt., 37.

25 Żurawski B., Gdy pies wyje i pohukuje sowa, „Wiedza i życie”11(1998)54. 


\section{Racjonalna źródła wampiryzmu}

Dzisiejsza wiedza pozwala wysunąć kilka racjonalnych wyjaśnień wampiryzmu, a jedną $\mathrm{z}$ nich jest przedwczesne pogrzebanie człowieka, jeszcze żywego. Liczne ofiary epidemii nie zawsze chowane były należycie. Uzasadniony pośpiech sprawiał, że grzebano nie zawsze osoby zmarłe. Były to zazwyczaj przypadki ludzi pogrążonych $w$ transie kataleptycznym ${ }^{26}$ lub w stanie zapaści. Osoby pochowane żywcem, przerażone szukały ratunku krzycząc i podejmując samodzielne próby wydostania się z trumny czy grobu. Czasami udawało im się wydostać, czasami umierały w męczarniach. Rozpaczliwe próby wydostania się z zamknięcia sprawiały, ze zwłoki przy ekshumacji znajdowano w nienaturalnych, konwulsyjnie wykrzywionych pozach, zaś wnętrze trumny pełne było krwi.

Innym przejawem wampiryzmu miało być pośmiertne puchnięcie ciała. Nadmierne opuchnięcie nieboszczyka najczęściej tłumaczono „utuczeniem się" wyssaną krwią. Medycyna współczesna zna liczne przypadki, w których ciało zmarłego może posiadać właśnie takie cechy. Zjawisko to nazwane jest dziś "gigantyzmem pośmiertnym" i spowodowane jest rozdęciem ciała wskutek gazów gnilnych, co daje efekt napuchnięcia ${ }^{27}$. Warto również zwrócić uwagę na zjawisko wydobywania się z ciała osoby zmarłej gazów gnilnych, uwolnionych w trakcie przebijania trupa ostrym przedmiotem np. kołkiem. Odgłos uwalnianych gazów często identyfikowano $\mathrm{z}$ westchnieniem uśmiercanego wampira.

Interesującym wytłumaczeniem wampiryzmu jest porfiria, nazywana również zespołem nabytym Günthera. Jest to zaburzenie metaboliczne spowodowane wrodzonymi lub nabytymi niedoborami enzymów biorących udział w biosyntezie hemu. U chorych cierpiących na porfirię dochodzi do zaburzeń metabolizmu porfiryn - związków chemicznych występujących w większości komórek organizmów żywych ${ }^{28}$. Porfiryny są związkami chemicznymi posiadającymi selektywną zdolność absorpcji światła widzialnego, i jako takie stanowią grupę cząsteczek biologicznych, których obecność w naturze ma fundamentalne znaczenie dla procesów produkcji i przetwarzania energii. Pod wpływem światła ulegają one wzbudzeniu, zaś nadmiar energii mogą przekazywać innym cząsteczkom, prowadząc do powstawania wysoce reaktywnych, toksycznych dla komórek, wolnych rodników tlenowych. W ostrym przebiegu choroby może nawet dochodzić do oparzeń. Jak pisze Kęciek: „już kilka minut oddziaływania promieni słonecznych,

26 Katalepsja (łac. catalepsis) to specyficzne zesztywnienie mięśni, połączone z zastyganiem postawy ciała oraz położeniu kończyn i wygięciu szyi w nienaturalnych pozycjach. Stan ten jest spowodowany wzmożonym napięciem mięśniowym, przy jednoczesnym upośledzeniu lub nawet całkowitym zablokowaniu czynności ruchowych chorego. Zesztywnienie to jest elastyczne, to znaczy ciałem chorego można poruszać.

27 Janion M., Wampir. Biografia symboliczna, Wyd. Słowo/Obraz \erytoria, Gdańsk 2004, 45.

28 Lipnicka A., Bianket ti J., Porfirie. Poradnik dla lekarzy i pacjentów, Warszawa 2007, 5. 
wystarczy by na twarzy i innych odkrytych częściach ciała powstały ropiejące pęcherze" 29 . W odmianie przewlekłej następuje tzw. bliznowacenie, wypadanie włosów (lub rzadziej ich nadmierny wzrost) i pogrubienie skóry w miejscach narażonych na światło. (por. fot.2)

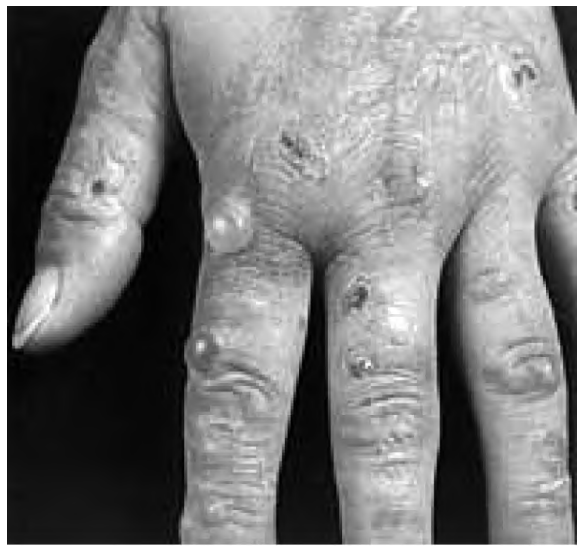

Fot. 2: Porfiria skórna

Szkodliwe substancje nagromadzone w tkankach odpowiedzialne są również za silnie czerwoną fluorescencję uzębienia chorych osób. Ponadto może dochodzić do obkurczanie dziąseł, przez co szyjki zębów ulegają odsłonięciu, i zęby w tym kły zdają się być dłuższe niż są. Chorobie towarzyszyć mogą także postępujące deformacje twarzy powstające $w$ wyniku zmian zapalno-martwiczych prowadzących do pojawienia się zniekształcających blizn. Spotykane są również przypadki utraty nosa czy palców, powstania wyjątkowo szpecących blizn, ściągnięcia warg i dziąseł. Ponieważ produkty metabolizmu porfiryn wydalane są $\mathrm{z}$ moczem lub kałem, te przybierają czerwoną barwę $e^{30}$. (por. fot.3)

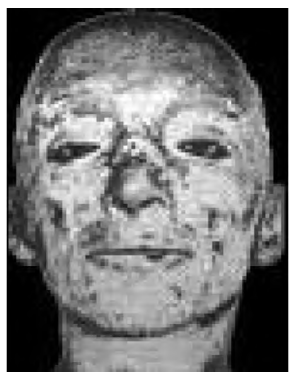

Fot. 3: Twarz chorego na porfirie

\footnotetext{
Kе̨CiEK K., Oko w oko $z$ bestia, „Fokus”6(2003)67.
}

30 Berg J.M., \ymoczko J.L., Stryer L., Biochemia, Wyd. Naukowe PWN, Warszawa 2005, 688. 
W przypadku porfirii wrodzonych nagromadzone w tkankach i płynach ustrojowych kwasy aminolewulinowe i porfibilinogeny, mają tendencję do atakowania układu nerwowego. W wyniku tego u chorych osób występują napady ostrych bólów brzucha i objawy neuropsychiczne. Dodatkowo mogą również pojawić się problemy natury psychicznej, takie jak: lęk, bezsenność, pobudzenie, splątanie i halucynacje, czy uczucie słabości kończyn.

Najprawdopodobniej jeden z królów angielskich Jerzy III (1738-1820) cierpiał na tą właśnie przypadłość. Uczyniła ona z niego szaleńca i przyczyniła się do utraty przez Brytyjczyków „kolonii amerykańskich”. Dokumentacja medyczna jego choroby była przechowywana w archiwach królewskich w Windsorze i to właśnie dzięki niej psychiatrzy wysnuli hipotezę porfirii ${ }^{31}$. Za porfiryka uważa się również Ludwika II Bawarskiego (1845-1886), zwanego również Ludwikiem Szalonym, który mieszkając w zamku Neuschwanstein, paranoidalnie zmieniał daty swego ślubu, cierpiał na bezsenność, zaś przed swoją śmiercią nie opuszczając swego zamku popadł w depresję ${ }^{32}$. Również porywczość i nieobliczalność Wincentego van Gogha wyjaśniana jest porfirią. Den holenderski artysta, uważany na najwybitniejszego malarza postimpresjonizmu w 1888 roku przenosi się do Arles (Prowansja). \u objawia się ukryta choroba. Po kolejnej kłótni malarz grozi przyjacielowi brzytwą i w stanie najwyższego wzburzenia obcina sobie ucho, które jak podają źródła, wręczył w kopercie miejscowej prostytutce. Zostaje umieszczony w miejscowym szpitalu. Odtąd ataki halucynacji i załamania nerwowe nawiedzając go coraz częściej, przeplatając się z okresami dobrego samopoczucia i jasności umysłu. W tym okresie van Gogh tworzy najwybitniejsze dzieła. Rok później mieszkańcy Arles, zmęczeni nieustannymi awanturami, wypędzają van Gogha z miasta. W maju artysta wyjeżdża i leczy się w szpitalu psychiatrycznym w St. Remy, gdzie stwierdzono epilepsję. Dziś uważa się, że symptomy choroby wskazują raczej na porfirię $e^{33}$.

Ponieważ dawniej choroba ta nie była znana, sądzono, że wywołują ją siły nieczyste. Dopiero w roku 1985 David Dolphin, profesor biochemii Uniwersytetu British Columbia w Vancouver rozpoczął badanie tej choroby. Jako pierwszy zwrócił on uwagę na podobieństwo klinicznego obrazu porfirii do tradycyjnych wyobrażeń o wampirach. Skupił się on głównie na rzadko występującej postaci choroby, na porfirii erytropoetycznej. Według niego widok człowieka, który unikał światła mógł przypominać wampira. \wierdzil ponadto, iż w związku z tym, że wrodzoną porfirię erytropoetyczną leczy się transfuzjami krwi, chorzy mogli

31 Cox T.M., Jack N., Lofthouse S., Watling J., Haines J., Warren M.J., King George III and porphyria: an elemental hypothesis and investigation, „Lancet”366(2005)332-335.

32 CARs J., Ludwik II Bawarski. Król rażony szaleństwem, PIW, Warszawa 1997.

33 WoLF P., Creativity and chronic disease Vicent van Gogh (1853-1890), "Western Journal of Medicine" 175(2001)5, 348. 
krew po prostu wypijać, łagodząc w ten sposób objawy choroby. Profesor zaproponował hipotezę tłumaczącą „anty-wampiryczne” działanie czosnku. Był on zdania, iż roślina ta zawiera składniki, które pogarszają objawy porfirii. Badania nad degradacją hemu, które prowadzone były przez grupę Dolphina wykazały, iż proces alkilacji, czyli przyłączania grupy alkilowej, może być odpowiedzialny za destrukcję cząsteczki hemu ${ }^{34}$. Allium sativum (czosnek), w którego skład wchodzi siarczek alkilu, jest chemicznym narzędziem niszczącym krew, co mogło wyjaśnić wstręt wampira przed tą rośliną. Jak się później okazało, zaproponowane wyjaśnienie zawiera jednak kilka słabych punktów. Dowiedziono bowiem, że czosnek porfirykom wcale nie szkodzi, a wypijanie krwi nie przynosi im ulgi, ponieważ hem ulega rozkładowi w przewodzie pokarmowym i staje się przez to bezużyteczny. Zaś postać wrodzonej porfirii erytropoetycznej, najbardziej odpowiadającej mitom o wampirach, występuje niezwykle rzadko - do tej pory na świecie zdiagnozowano około 200 przypadków.

Kolejną próbą wyjaśniania wampiryzmu jest nekrofilia i nekromania. 冈a pierwsza polega na zaspokajaniu popędu płciowego przez spółkowanie z umarłymi, zaś druga to fascynacja śmiercią i osobą zmarłą pozbawioną jednak charakteru erotycznego. Jako pierwszy nazwy te wprowadził w XIX wieku H. Guislain. Erich Fromm wymienia dwa rodzaje tego zjawiska: nekrofilia seksualna - pożądanie stosunku seksualnego lub innego rodzaju seksualnego kontaktu z ciałem martwej osoby oraz nekrofilia nieseksualna - pragnienie dotykania zwłok, znajdowania się w ich pobliżu i spoglądania na nie, a w szczególności pragnienia ich rozczłonkowywania. Dewiacja przez niektórych kojarzona jest ze skłonnościami sadystycznymi i może występować w postaci wampiryzmu ${ }^{35}$. W encyklopedii $L e$ musée des vampires autorzy Villeneuve’a i Degaudenzi’ego określają nekrofilię jako inwersję wampiryzmu, będącą niepokojeniem zmarłego w celach seksualnych.

\section{Współczesny wampiryzm}

Dwudziestego piątego sierpnia 1997 został powołany Międzyresortowy Zespół ds. Nowych Ruchów Religijnych ${ }^{36}$. Opublikował on w 2000 roku raport o niektórych zjawiskach związanych z działalnością sekt w Polsce, a wśród nich wyodrębnił sekty wampiryczne. Członkowie tych sekt tworzą zamknięte klany,

34 GUdowsKa-Nowak E., Demitologizacja symboli, czyli o wampirach, nanorurkach i tajemnicach porfiryn, "Foton"93(2006)27-28.

35 Fromm E., Anatomia ludzkiej destrukcyjności, Dom Wyd. Rebis, Poznań 1998, 366.

36 Zarządzenie Nr 78 Prezesa Rady Ministrów z 25 sierpnia 1997 w sprawie w sprawie powołania Międzyresortowego Zespołu do Spraw Nowych Ruchów Religijnych. „Monitor Polski”54(1997), poz.513. 
organizują we własnym gronie spotkania, podczas których spożywana jest krew. Ich zdaniem, wypijana krew wywołuje stany euforii i „psychicznego orgazmu”. Morfeusz, jeden z członków sekty, na stronach Internetu opisuje swoje odczucia: „Pierwszy raz piłem krew mojej dziewczyny - wspomina. Czujesz radość, psychiczny orgazm, jakbyś rodził się na nowo. Najbardziej podniecające jest, gdy pijesz krew innego wampira. Dostajesz krew wszystkich jego poprzednich dawców $(. . .)^{\prime 37}$. Wraz ze wzrostem zaawansowania i zaangażowania praktyki wampiryczne stają się bardziej wyrafinowane - członkowie grupy zaczynają sypiać w trumnach i odprawiać okultystyczne rytuały. Niektórzy dodatkowo akcentują swoją naturę przez ostrzenie zębów.

Członkowie tych sekt uzasadniają swoje praktyki argumentami filozoficzno-religijnymi. Posługują się fragmentami kabały, ksiąg ezoterycznych, czy poradników okultystycznych. Są przekonani, że spożywanie krwi dostarcza im tajemną wiedzę, pozwala posiąść cechy swojej ofiary, energię duchową, która wynosi ich ponad przeciętność. Kandydaci tych sekt, podobnie jak innych, rekrutowani są zazwyczaj przez Internet $z$ list dyskusyjnych. Na tym etapie selekcji nowicjusz powinien wykazać się znajomością tematyki i terminologii funkcjonującej w tych zgromadzeniach. Ważnym elementem jest również stosunek do religii chrześcijańskiej - rekrutowany powinien okazać niechęć, bądź przynajmniej obojętność. Dopiero po przejściu tego etapu zapraszany jest na osobiste spotkanie.

Współcześnie rozróżnia dwa typy wampiryzmu: krwi oraz energii. Pierwsze $\mathrm{z}$ nich, najczęściej spotykane, to Sanguinianie (łac. sanguis - krew), spożywający krew ludzką lub innego wampira. Dzięki krwi mogą oni normalnie funkcjonować przez ok. 2/3 tygodnia od jej wypicia. Najczęściej pobierają ją z ręki lub szyi, tam gdzie skóra jest cienka. Na stronach zrzeszeń można napotkać na szczegółowe opisy narzędzi, którymi posługują się wampiry krwi: nóż (mało popularny ze względu na pozostawiane blizny i długo gojące się rany), igła (nie pozostawia śladów na skórze, ale daje mały efekt i sprawia ból), żyletka (popularna, pozostawia małe blizny, zaś rany szybko się goją) oraz skalpel (najpopularniejszy, najczęściej stosowany $\mathbf{u}$ "najstarszych" wampirów, nacinanie nim nie sprawia prawie żadnego bólu, a rany szybko się goją).

Drugim, wyróżnianym typem są wampiry pobierające energię $w$ „czystej postaci" (zwane PSI) i dzielą się na dwie grupy: emocjonalne i astralne. Pierwsze czerpią energię z silnych emocji - przeważnie ludzkich - w różnych formach, np. wyzwalanych podczas stosunku seksualnego, czy bójki. Wampir astralny jest zaawansowaną formą PSI, pobiera on "moc" z energetycznych punktów człowieka, nazywanych czakrami. Są to słabe miejsca na ciele człowieka, najczęściej okolice karku.

37 http://student.agh.edu.pl/ $\sim$ monku/rh_plus/viewtopic.php?t=55\&sid=60eb285042b380fe$88421998 \mathrm{c} 76631 \mathrm{ba}$ 
Często symbolem używanym współcześnie przez czlonków sekt wampirycznych jest krzyż Ankh (crux ansata). Znak ten zaczerpnięty został z kultury starożytnego Egiptu, gdzie uznawano go za paginację fizycznego i nieśmiertelnego życia. Symbol ten dawał - poprzez emanowane energii - nieśmiertelność i wieczne zdrowie. W języku starożytnym Kemetu hieroglif ten oznaczał „życie”. Symbol ten został następnie przejęty przez Fenicjan i za ich sprawą stał się znany w świecie semickim. Krzyż Ankh nie jest związany z historią wampirów, został sztucznie zaabsorbowany przez członków sekt. Połączenie to jest dość niefortunne, z uwagi na fakt, iz Ankh powiązany był pierwotnie z kultem słonecznym, od którego przecież „prawdziwy” wampir stroni. (por. fot.4)

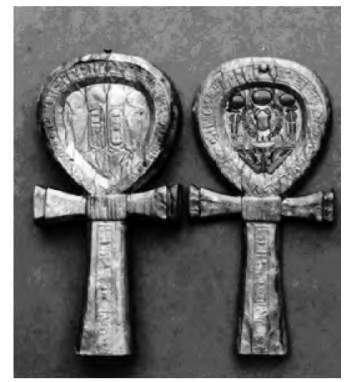

Fot. 4: Symbol Ankh. [Ashmolean Museum, Oxford]

Credo wampira umieszczone w wampirycznej biblii brzmi:

"Jestem Wampirem, czczę moje ego i czczę moje życie, ponieważ jestem jedynym istniejącym Bogiem.

Jestem dumny z tego, iż żeruję na ludziach i oddaję honor moim zwierzęcym instynktom.

Egzaltuję mój racjonalny umysł i nie utrzymuję żadnych wierzeń, które są wbrew rozumowi.

Rozpoznaję różnicę pomiędzy światami prawdy i fantazji.

Uznaję za fakt, iż przetrwanie jest najwyższym prawem.

Uznaję, iż Dar Ciemności musi być ukryty według naturalnego prawa, dzięki któremu mogę tworzyć mą magię.

Wiem, że moja wiara w Rytuały jest fantazją lecz magia jest prawdziwa, i szanuję i uznaję wyniki mej magii.

Wyznaję, iż nie ma nieba takowoż i piekła, a śmierć postrzegam jako zniszczenie życia.

Dlatego czynię najwięcej tu i teraz.

Jestem Wampirem.

Pokłoń się przede mną̧"38.

38 http://www.vampiry.wwt.pl/glowna/magia/biblia.html, tłum. Dopola Fleur du Sang, Biblia Wampiryczna. 


\section{Zakończenie}

Cechą kultury naszego gatunku jest z jednej strony jej konserwatyzm, $\mathrm{z}$ drugiej zaś dynamizm. Konserwatyzm wyraża się w starej prawdzie, że współczesne wierzenia mają archaiczne początki, a te bywają najtrwalsze. Dynamizm natomiast manifestuje się w tym, że pierwotne wyobrażenia, trafiając na „urodzajną glebę", pozyskują ostatecznie zupełnie nową formę. Wampiryzm właśnie wykazuje wspomnianą prawidłowość. Będąc formą wiary w życie po śmierci sięga swymi korzeniami w odległą przeszłość, natomiast dziś, ze względu na uwarunkowania XXI wieku, przybiera całkowicie odmienne oblicze.

\section{SUMMARY}

Every myth, regardless of its nature, refers back to some event placed in illio tempore. By this fact it constitutes a pattern to all situations and activities in which the event may reappear. The myth can degrade into an epical legend, a ballad or a roman, but it can also survive in a limited form in superstitions, customs and longings without losing neither its structure nor its meaning. In the history of mankind, the perception contributed to the formation of culture - the total of artifacts, both material and immaterial (spiritual or symbolic). These achievements, characteristic for particular society, constitute a model of social behavior. While interpreting the external world people relied on supernatural explanations to some extent, which depended on the level of intellectual development. Initially many facts were explained with the interference of dark, demonic powers, adopting diverse forms in people's imagination. Thanks to such interpretation of reality the vampire was born to existence.

The vampire has undergone a peculiar evolution, the features of its character often changed and the figure was many times reborn in varied forms. Settled in present times, the silhouette of the vampire remains realistic in some people's minds and has no tendency to modify. Its presence in modern times is mainly perceptible through the creation and development of vampire - worshiping sects.

The following thesis is aimed to present the evolution of beliefs and picture of the vampire, as well as ancient practices and ways of treating people suspected of vampirism. The text enables a close look into the structure and functioning of modern vampire-related cults, it also attempts to explain the phenomenon of vampirism and its continuously increasing popularity. 